\title{
METODOLOŠKE OSNOVE ZA DEKOMPOZICIJU BRUTO DOMAĆEG PROIZVODA NA SASTAVNICE FINALNE POTRAŽNJE I PRIMJENA NA HRVATSKO GOSPODARSTVO
}

Cilj rada je sustavan prikaz metodoloških osnova za dekompoziciju bruto domaćeg proizvoda na komponente finalne potražnje i primjena prikazanog modela na hrvatsko gospodarstvo. Dekompozicija bruto domaćeg proizvoda temelji se na input-output modelu. Za razliku od konvencionalnog pristupa izračuna doprinosa pojedinih sastavnica rashodne strane bruto domaćeg proizvoda u kojem se uvoz promatra kao neovisna varijabla, temeljem predloženog modela uvoz se raspodjeljuje na sastavnice finalne potražnje koje ga izravno i neizravno induciraju. Na taj način dobiva se realniji prikaz doprinosa svake od komponenti finalne potražnje. Primjena metodologije za dekompoziciju bruto domaćeg proizvoda na sastavnice finalne potražnje empirijski je primijenjena za hrvatsko gospodarstvo. Na temelju rezultata provedene analize može se zaključiti da su izvoz i investicije sastavnice finalne potražnje sa visokom razinom uvoznog sadržaja. S druge strane najniži uvozni sadržaj ustanovljen je za kategoriju izdataka države za finalnu potrošnju. Rezultati rada impliciraju da novi model ekonomskog rasta temeljen na rastu izvoza $i$ investicija u bruto fiksni kapital nužno podrazumijeva $i$ veću razinu međunarodne integriranosti hrvatskog gospodarstva. Ograničenja

\footnotetext{
${ }^{*}$ Dr. sc. D. Mikulić, znanstveni savjetnik u trajnom zvanju, Ekonomski institut, Zagreb (E-mail: dmikulic@eizg.hr).

Rezultati istraživanja prikazani u članku se temelje na knjizi Mikulić, D. (2018) Osnove input-output analize s primjenom na hrvatsko gospodarstvo, Ekonomski institut, Zagreb.

Rad je primljen u uredništvo 06.10.2018. godine, a prihvaćen je za objavu 21.11.2018. godine.
} 
istraživanja proizlaze iz primjene standardne pretpostavke korištene u inputoutput analizi o fiksnim tehnološkim koeficijentima. Doprinos rada sastoji se u pružanju metodološke osnove koja omogućuje precizniju kvantifikaciju doprinosa pojedinih sastavnica finalne potražnje u odnosu na dosadašnji konvencionalni pristup.

Ključne riječi: input-output analiza, bruto domaći proizvod, finalna potražnja, uvozna ovisnost

\section{Uvodna razmatranja}

U makroekonomskim analizama uobičajeno se primjenjuje tradicionalni pristup izračuna doprinosa pojedinih sastavnica finalne potražnje. Takav pristup proizlazi iz definicije bruto domaćeg proizvoda (BDP) kao sume osobne i državne potrošnje, investicija i izvoza umanjenog za uvoz. Prema računovodstvenom identitetu, stopa rasta BDP-a jednaka je zbroju rasta sastavnica potražnje ponderiranih udjelom u ukupnom BDP-u (s korištenjem negativnog predznaka za uvoz). Ovakav pristup zanemaruje činjenicu da rast uvoza nije neovisna varijabla, već njegovo kretanje ovisi o kretanju uvoznog sadržaja u sastavnicama domaće finalne potražnje.

Cilj rada je prikazati metodološke osnove za dekompoziciju bruto domaćeg proizvoda na sastavnice finalne potražnje temeljem input-output modela. Korištenjem input-output modela kretanje uvoza može se objasniti promjenom domaće potražnje. Određeni dio domaće potražnje izravno se zadovoljava uvoznim proizvodima i uslugama, dok neizravni uvoz predstavlja uvoz intermedijarnih dobara i usluga koji je potreban u proizvodnim procesima domaćih proizvođača.

Rad primjenjuje tradicionalnu input-output metodologiju temeljem raspoloživih podataka za međusektorske isporuke raščlanjene na domaće i uvozne tokove. Doprinos rada sastoji se u pružanju metodološke podloge za jasniju identifikaciju učinaka pojedinih komponenti finalne potražnje na ukupnu domaću aktivnost, budući se uvoz ne tretira kao egzogena varijabla već je pridružen sastavnici finalne potražnje koja ga izravno ili neizravno inducira. Ograničenja rada proizlaze iz primjene standardne pretpostavke korištene $u$ input-output analizi o fiksnim tehnološkim koeficijentima, te neraspoloživosti input-output tablica za više godina u stalnim cijenama, a koje bi se temeljile na istoj klasifikacijskoj razini i metodologiji.

Rad je strukturiran na način da nakon uvodnih napomena slijedi kratak pregled literature o input-output analizi s primjenom na izračun doprinosa pojedinih sastavnica finalne potražnje. Treći dio rada prikazuje metodološke osnove za dekompoziciju BDP-a, dok su rezultati primjene predloženog modela testirani u 
četvrtom poglavlju. Na kraju rada prikazani su osnovni zaključci, ograničenja i pravci budućih istraživanja.

\section{Pregled literature}

Input-output model prikazuje sustav linearnih jednadžbi koje opisuju strukturne odnosa između ekonomskih sektora koji su aktivni na nacionalnom teritoriju neke zemlje. Svaka jednadžba prikazuje strukturu isporuka određenog sektora drugim sektorima za intermedijarnu potrošnju i finalne uporabe. Područja primjene input-output analize detaljno su obrađena u ekonomskoj literaturi, a neki od najčešće citiranih autora su Leontief (1986), Miller i Blair (1985), Fleissner i sur. (1993), United Nations (1999), Kurz, Dietzenbacher i Lager (1998) i ten Raa (2005). Input-output analiza sustavno prati tokove dobara i usluga između različitih sektora u gospodarstvu. Struktura je proizvodne aktivnosti svakog sektora predstavljena pripadajućim strukturnim koeficijentima koji kvantitativno opisuju veze između inputa koji se troše u proizvodnom procesu i outputa koji su rezultat proizvodnog procesa.

Autor koji je dao najveći doprinos razvitku ove metode jest Wassily Leontief koji je za svoj doprinos u idejnom i analitičkom smislu za razvitak novog istraživačkog područja dobio Nobelovu nagradu 1973. godine. Osnovni model prikazuje kako se putem međusektorske zavisnosti egzogena promjena u pojedinoj komponenti finalne potražnje rasprostire na cijelo gospodarstvo te se inicijalni učinci multipliciraju na sve sektore nacionalnog gospodarstva. U suvremenoj literaturi model se često proširuje u matrice društvenog računovodstva koje dodatno prikazuju distribuciju i preraspodjelu dohotka između različitih sektora nacionalnog gospodarstva. U novijem razdoblju razvijeni su modeli koji povezuju nacionalne input-output tablica u takozvane međunarodne ili čak svjetske input-output tablica (Timmer, Dietzenbacher, Los, Stehrer i de Vries, 2015).

U Hrvatskoj je tijekom prošlog stoljeća postojala duga tradicija razvitka input-output metodologije (Babić, 1978; Babić, 1980, Babić, 1983; Sekulić, 1977; Sekulić, 1980; Sekulić, 1993; Jurčić, 1998). Obuhvatan pregled teorijskih i empirijskih doprinosa domaćih autora dan je u Jurčić (2000). Od osamostaljenja Hrvatske pa sve do nedavno, ova tehnika analize uglavnom je zanemarena, što je primarno posljedica činjenice kako sve donedavno nije postojala input-output tablica za hrvatsko gospodarstvo. Dostupnost službenih input-output tablica omo-

gućila je primjenu ove metodologije na proučavanje doprinosa pojedinih sektora nacionalnom gospodarstvu poput prehrambene industrije (Buturac i Vizek, 2015; Buturac, Lovrinčević i Mikulić, 2017), tekstilne industrije (Buturac, Lovrinčević 
i Mikulić, 2014) drvne industrije (Lovrinčević, Buturac i Mikulić, 2015.) turizma (Ivandić i Šutalo, 2018), prerađivačke industrije (Buturac, Mikulić i Palić, 2019) ili pak učinaka pojedinih mjera energetske učinkovitosti (Mikulić, Rašić-Bakarić i Slijepčević, 2016; Keček, Mikulić i Lovrinčević, 2019).

Problem kvantificiranja doprinosa pojedine komponente finalne potražnje najčešće je analiran u radovima koji se bave paradigmom rasta temeljenog na izvozu (eng. Export-led growth). Liberalizacija trgovine i stvaranje internacionalnih proizvodnih lanaca utječu na znatan porast uvoznog sadržaja u domaćoj proizvodnji, posebice kod gospodarstava s visokom razinom otvorenosti. Povećana upotreba uvoznih intermedijarnih inputa postala je ključna karakteristika procesa vertikalne specijalizacije (Hummels, Ishii i Yi, 2001). Korištenje tradicionalnog koncepta izračuna doprinosa koji se najčešće primjenjuje (umnožak stope rasta izvoza i udjela izvoza u BDP-u), u određenom smislu precjenjuje stvaran doprinos rasta izvoza, budući je dio takvog rasta poništen rastom uvoza. Uz povećan uvozni sadržaj, rast dodane vrijednosti domaćih proizvođača u određenoj mjeri zaostaje za rastom izvoza.

Mellens, Noordman i Verbruggen (2007) su analizom 10 gospodarstva zaključili da reeksport bilježi brže stope rasta od izvoza proizvoda domaćeg porijekla, posebice u nekim zemljama poput Singapura i Hong Konga koje zbog geografskih ili političkih razloga posreduju u međunarodnoj razmjeni. Ustanovili su da je reeksport u analiziranom razdoblju čine čak 95 posto izvoza iz Hong Konga, te više od 50 posto izvoza iz Singapura i Nizozemske. U takvim slučajevima podaci o izvozu, koji u nekim od navedenih gospodarstava iznosi i više od ukupnog BDP-a, ne govore mnogo o doprinosu izvoza domaćoj ekonomskoj aktivnosti. Učinak na domaću aktivnost kod reeksporta jednak je samo posredničkoj marži, odnosno razlici između vrijednosti po kojoj je roba izvezena u treću zemlju i vrijednosti proizvoda uvezenog iz zemlje porijekla. Nalazi iz ovog istraživanja posebice su aktualni u slučaju Hrvatske gdje se u razdoblju nakon ulaska u Europsku uniju može uočiti značajno brži rast ukupnog izvoza u odnosu na domaću proizvodnju.

Intenzivna liberalizacija trgovine i tokova kapitala u posljednjih tridesetak godina utjecala je na povećanje uvoznog sadržaja u ukupnom lancu dodane vrijednosti čak i za proizvode namijenjene domaćem tržištu. Ipak, uočeno je da je u pravilu uvozna zavisnost veća u odnosu na proizvodnju namijenjenu domaćem tržištu, uglavnom zbog značajnog udjela međunarodno nerazmjenjivih osobnih usluga koje čine značajan udio u potrošnji kućanstava. U skupini gospodarstava koja zaostaju za tehnološki najrazvijenijim zemljama, visok udio uvoznog sadržaja karakterističan je i za kategoriju investicija u fiksni kapital.

Primjenom input-output modela, ukupan uvoz moguće je alocirati na sve komponente domaće potražnje i izvoza, a koje izravno ili neizravno koriste pro- 
izvode uvoznog porijekla. Empirijska istraživanja uglavnom su provedena za razvijenija gospodarstva, a temelje se uobičajeno na OECD bazi input-output tablica. Nacionalni statistički uredi Nizozemske, Kanade, Francuske i Danske koriste input-output tablice za procjenu doprinosa komponenta rashodne strane BDP-a. Kranendonk i Verbruggen (2008) prikazuju procjene uvoznog sadržaja za zemlje eurozone i SAD. Uvoz je raščlanjen na sljedeće komponente: osobnu potrošnju, državnu potrošnju, investicije i izvoz. Autori zaključuju da je izvoz na razini prosjeka eurozone sastavnica potražnje sa najintenzivnijim potrebama za proizvodima i uslugama uvoznog porijekla. Izvoz izravno i neizravno inducira više od 50 posto ukupnog uvoza navedene skupine zemalja. Od ostalih sastavnica finalne potražnje, utvrđeno je da je uvozni sadržaj po jedinici finalne potražnje veći za investicije u odnosu na potrošnju kućanstava. Ipak, zbog činjenice da je po apsolutnim vrijednostima osobna potrošnja u svim analiziranim gospodarstvima gotovo trostruko veća od investicija, izravan uvoz ili uvoz ugrađen u domaće proizvode inducira u prosjeku približno trećinu ukupnog uvoza. Najniža razina uvoznog sadržaja zabilježena je za komponentu potrošnje države. Takav rezultat je u skladu s očekivanja budući se najveći dio državne potrošnje odnosi na međunarodno nerazmjenjive usluge poput javne uprave, obrane, obrazovanja i zdravstva.

Zanimljiv nalaz istraživanja odnosi se na uočene razlike između konvencionalnog izračuna doprinosa pojedinih sastavnica finalne potražnje i korigiranog doprinosa koji isključuje učinak induciranog uvoza. Dok konvencionalni računovodstveni pristup rezultira negativnim doprinosom međunarodne razmjene (doprinos izvoza umanjen za doprinos uvoza), pristup u kojem je uvoz raspodijeljen na sve sastavnice finalne potražnje ukazuje da doprinos izvoza čini gotovo trećinu ukupnog rasta BDP-a (Kranendonk i Verbruggen, 2008). Ostale sastavnice finalne potražnje, u slučaju korekcije za inducirani uvoz, pokazuju manji doprinos rastu BDP-a u odnosu na konvencionalni pristup.

Hummels i suradnici (2001) uz razvijenija gospodarstva u uzorak uključuju i nekoliko manje razvijenih gospodarstava: Koreju, Tajvan i Meksiko. Utvrdili su da je uvozni sadržaj izvoza u Koreji i Tajvanu sredinom 90-tih godina prošlog stoljeća iznosio između 30 i 40 posto.

\section{Metodologija za dekompoziciju doprinosa sastavnica finalne potražnje}

U sustavu nacionalnih računa bruto domaći proizvod može se izračunati primjenom tri različita pristupa: proizvodnog, dohodovnog ili rashodnog pristupa. Prema proizvodnom pristupu BDP je jednak razlici između ukupne domaće proi- 
zvodnje (u tržišnim cijenama s uključenim neto porezima na proizvode) i intermedijarne potrošnje. Prema dohodovnom pristupu BDP je zbroj ostvarenih dohodaka koji se dijele na faktore proizvodnje rad i kapital, te indirektnih poreza. Prema rashodnom pristupu BDP je zbroj finalne potražnje umanjene za uvoz. Stoga vrijedi identitet:

$$
\mathrm{BDP}=\mathrm{P}-\mathrm{M}=\mathrm{W}+\mathrm{O}+\operatorname{Tind}=\mathrm{C}+\mathrm{I}+\mathrm{G}+\mathrm{E}-\mathrm{U} \text {. }
$$

Kretanje neke od navedenih varijabli nije neovisno o kretanju ostalih varijabli. Nije ispravan zaključak da promjena neke od sastavnica finalne potražnje (primjerice osobne potrošnje) automatski dovodi do promjene bruto domaćeg proizvoda u istom iznosu za koji se promijenila ta varijabla. Učinak promjene osobne potrošnje (a isto vrijedi i za ostale sastavnice finalne potražnje), osim izravnog povećanja bruto proizvodnje sektora koji isporučuje finalno dobro ili uslugu, utječe i na porast proizvodnje ostalih sektora. Dobavljači koji proizvode intermedijarne proizvode namijenjene upotrebi u proizvodnim procesima kojima se proizvode dobra i usluge namijenjene finalnoj potrošnji također povećavaju vrijednost isporuka. S druge strane, porast osobne potrošnje utječe i na izravan porast uvoza za dio osobne potrošnje koji se zadovoljava proizvodima uvoznog podrijetla, ali i neizravan porast uvoza intermedijarnih dobara i usluga potrebnih za proizvodne procese domaćih proizvođača koji isporučuju finalno dobro ili uslugu.

Input-output okvir je pogodan za izračun ukupnog izravnog i neizravnog učinka svake od komponenti finalne potražnje. Njegovom se primjenom mogu identificirati multiplikativni učinci, ali i izravan i neizravan uvoz sadržan u pojedinim finalnim isporukama. Dekompozicija ukupne proizvodnje, intermedijarne potrošnje, zaposlenosti i indirektnih poreza na doprinos pojedine sastavnice finalne potražnje može se napraviti korištenjem skupa jednadžbi koje su detaljno opisane u drugom poglavlju knjige.

Finalnu potražnju potrebno je razdvojiti najprije na potražnju za domaćim odnosno uvoznim proizvodima koja se potom razdvaja u vektor stupce koji obuhvaćaju pojedine sastavnice potražnje, te je:

$$
\mathbf{f}=\mathbf{f}^{\mathrm{D}}+\mathbf{f}^{\mathrm{U}}
$$

Vrijednost finalne potražnje jest zbroj pojedinih sastavnica, te je finalna potražnja za domaćim dobrima i uslugama:

$$
\mathbf{f}^{\mathrm{D}}=\mathbf{c}^{\mathrm{D}}+\mathbf{g}^{\mathrm{D}}+\mathbf{i}^{\mathrm{D}}+\mathbf{e}^{\mathrm{D}}
$$


a finalna potražnja za dobrima i uslugama uvoznog podrijetla:

$$
\mathbf{f}^{\mathrm{U}}=\mathbf{c}^{\mathrm{U}}+\mathbf{g}^{\mathrm{U}}+\mathbf{i}^{\mathrm{U}}+\mathbf{e}^{\mathrm{U}}
$$

U sustavu nacionalnih računa, tablice ponude i uporabe izrađuju se najčešće u bazičnim cijenama. Iznos neizravnih poreza na dobra i usluge po proizvodima i uslugama u simetričnim input-output tablicama ponude i uporabe dostupan je samo na razini ukupnih sastavnica finalne potražnje. Ukupne vrijednosti pojedinih sastavnica u tržišnim kupovnim cijenama mogu se izračunati dodavanjem indirektnih poreza na proizvode na zbroj domaćih i uvoznih uporaba. Treba primijetiti da je u matričnom iskazu svaka sastavnica finalne potražnje za domaću odnosno inozemnu komponentu prikazana vektor stupcem. Input-output tablice prema transmisijskom programu Eurostata sadrže raščlambu gospodarstva na 64 proizvodna sektora, te vektor stupac $\mathbf{c}^{\mathrm{D}}$ (izdaci za potrošnju kućanstava na dobra i usluge domaćeg porijekla) sadrži 64 elementa koji prikazuju vrijednost osobne potrošnje koja je zadovoljena domaćim proizvodima odgovarajućih 64 proizvodna sektora. Isto tako, vektor stupac $\mathbf{c}^{\mathrm{U}}$ sadrži 64 elementa koji prikazuju strukturu osobne potrošnje zadovoljene proizvodima uvoznog podrijetla.

Izravni neto porezi na proizvode $u$ tablicama prema transmisijskom programu Eurostata dostupni su samo na razini ukupne osobne potrošnje (samo jedan element, odnosno matrica reda 1 x 1), a ukupna osobna potrošnja u tržišnim kupovnim cijenama $\mathrm{C}$ (vrijednost, a ne matrica) jednaka je zbroju $\mathbf{i c}^{\mathrm{D}}+\mathbf{i c}^{\mathrm{u}}+\mathrm{Ctdir}$, pri čemu je i sumarni vektor redak s odgovarajućim brojem jedinica (u konkretnom slučaju 64).

Ukupna vrijednost domaće proizvodnje koja je izravno i neizravno potrebna za zadovoljenje zadane finalne potražnje jednaka je umnošku Leontijevljeve inverzne matrice $\left(\mathbf{I}-\mathbf{A}^{\mathrm{D}}\right)^{-1}$ za domaću proizvodnju i finalne potražnje za domaćim proizvodima $\left(\mathbf{f}^{\mathrm{D}}=\mathbf{c}^{\mathrm{D}}+\mathbf{g}^{\mathrm{D}}+\mathbf{i}^{\mathrm{D}}+\mathbf{e}^{\mathrm{D}}\right)$.

U procesu dekompozicije ukupne proizvodnje na pojedine sastavnice, ukupna domaća proizvodnja koja je potrebna za izravno i neizravno zadovoljenje osobne potrošnje $\left(\mathbf{x}_{\mathbf{c}}\right)$ jednaka je:

$$
\mathbf{x}_{\mathbf{C}}=\left(\mathbf{I}-\mathbf{A}^{\mathrm{D}}\right)^{-1} \mathbf{c}^{\mathbf{D}}
$$

Na isti način izračunava se i domaća proizvodnja koja je potrebna za zadovoljenje ostalih sastavnica finalne potražnje, zamjenom $\mathbf{c}^{\mathrm{D}}$ odgovarajućim vektor stupcem finalne uporabe: državnom potrošnjom $\left(\mathbf{g}^{\mathrm{D}}\right)$, bruto investicijama u fiksni kapital i povećanjem zaliha $\left(\mathbf{i}^{\mathrm{D}}\right)$, odnosno izvoznim isporukama dobara i usluga 
$\left(\mathbf{e}^{\mathrm{D}}\right)$. Ukupna domaća proizvodnja koja je izravno (izravne isporuke sektorima nositeljima finalne potražnje) ili neizravno (isporuke intermedijarnih dobara između sektora koji su u proizvodnom lancu sektora koji izravno isporučuju dobra i usluge finalnim potrošačima) potrebna za zadovoljenje finalne potražnje na taj se način raščlanjuje na pojedine sastavnice finalne potražnje. Tako je:

$$
\begin{aligned}
& \mathbf{x}_{\mathrm{C}}=\left(\mathbf{I}-\mathbf{A}^{\mathrm{D}}\right)^{-1} \mathbf{c}^{\mathrm{D}}, \\
& \mathbf{x}_{\mathrm{G}}=\left(\mathbf{I}-\mathbf{A}^{\mathrm{D}}\right)^{-1} \mathbf{g}^{\mathrm{D}}, \\
& \mathbf{x}_{\mathrm{I}}=\left(\mathbf{I}-\mathbf{A}^{\mathrm{D}}\right)^{-1} \mathbf{i}^{\mathrm{D}}, \\
& \mathbf{x}_{\mathrm{E}}=\left(\mathbf{I}-\mathbf{A}^{\mathrm{D}}\right)^{-1} \mathbf{e}^{\mathrm{D}}, \\
& \mathbf{x}=\mathbf{x}_{\mathrm{C}+} \mathbf{x}_{\mathrm{G}+} \mathbf{x}_{\mathrm{I}+} \mathbf{x}_{\mathrm{E} .}
\end{aligned}
$$

Vektor stupci ukupne domaće proizvodnje (u konkretnom slučaju vektor stupac sadrži 64 retka) sadrže elemente koji prikazuju iznos domaće proizvodnje potrebne za zadovoljenje domaće potražnje za svaki od 64 proizvodna sektora. Finalne isporuke $\mathrm{u}$ jednadžbama su grupirane u četiri kategorije sukladno osnovnim makroekonomskim jednadžbama. Ukoliko je predmet istraživanja pojedina potkategorija finalne uporabe i ako postoje dovoljno detaljni skupovi podataka, sastavnice finalne potražnje se mogu dodatno raščlaniti. Primjerice, u pojedinim istraživanjima o socioekonomskim kategorijama kućanstava, ukupna se osobna potrošnja može raščlaniti na potrošnju pojedinih kategorija kućanstava (npr. potrošnja po dohodovnim decilima), investicije se mogu raščlaniti na investicije u bruto fiksni kapital i promjenu zaliha, državna potrošnja na individualnu i zajedničku, a izvoz na izvoz dobara i usluga. Metodologija dekompozicije u tim slučajevima je ista, ali takvi izračuni sadrže više vektor stupaca finalne potražnje sukladno predmetu istraživanja.

Osim dekompozicije ukupne proizvodnje, primjenom input-output modela može se utvrditi i doprinos pojedinih sastavnica finalne potražnje u terminima bruto dodane vrijednosti (na razini ukupnog BDV-a ili pojedinih sastavnica - bruto naknade zaposlenicima, ostalih neto poreza na proizvodnju, bruto poslovnog viška). U tom slučaju potrebno je predmnožiti desnu stranu iskaza u jednadžbama s input-output koeficijentima za bruto dodanu vrijednost.

Ukupna bruto dodana vrijednost može se raščlaniti na BDV koji proizlazi iz proizvodnih aktivnosti poduzetih za zadovoljenje pojedine sastavnice finalne potražnje. 
D. MIKULIĆ: Metodološke osnove za dekompeziciju bruto domaćeg proizvoda na sastavnice finalne potražnje... EKONOMSKI PREGLED, 70 (3) 451-476 (2019)

$$
\begin{aligned}
& \mathrm{BDV}=\mathrm{V}_{\mathrm{C}+} \mathrm{V}_{\mathrm{G}+} \mathrm{V}_{\mathrm{I}+} \mathrm{V}_{\mathrm{E},} \\
& \mathrm{V}_{\mathrm{C}}=\mathbf{v}^{\mathrm{T}}\left(\mathbf{I}-\mathbf{A}^{\mathrm{D}}\right)^{-1} \mathbf{c}^{\mathrm{D}}, \\
& \mathrm{V}_{\mathrm{G}}=\mathbf{v}^{\mathrm{T}}\left(\mathbf{I}-\mathbf{A}^{\mathrm{D}}\right)^{-1} \mathbf{g}^{\mathbf{D}}, \\
& \mathrm{V}_{\mathrm{I}}=\mathbf{v}^{\mathrm{T}}\left(\mathbf{I}-\mathbf{A}^{\mathrm{D}}\right)^{-1} \mathbf{i}^{\mathrm{D}}, \\
& \mathrm{V}_{\mathrm{E}}=\mathbf{v}^{\mathrm{T}}\left(\mathbf{I}-\mathbf{A}^{\mathrm{D}}\right)^{-1} \mathbf{e}^{\mathrm{D}} .
\end{aligned}
$$

Input-output koeficijenti za bruto dodanu vrijednost $\left(\mathbf{v}^{\mathrm{T}}\right)$ najčešće su iskazani kao vektor redak (reda $1 \times$ 64) pri čemu svaki element prikazuje udio bruto dodane vrijednosti u bruto outputu svakog od proizvodnih sektora. Ponekad su koeficijenti bruto dodane vrijednosti iskazani kao matrica $\mathbf{V}$ s recima koji pokazuju udio pojedine komponente bruto dodane vrijednosti (bruto naknada zaposlenicima, ostali neto porezi na proizvodnju, bruto poslovni višak) u vrijednosti proizvodnje, što mijenja način izračuna i interpretaciju. Ovaj slučaj se ovdje neće razmatrati, već će u nastavku biti prikazan izračun ukupne bruto dodane vrijednosti po sektorima, bez raščlambe na pojedine kategorije dohotka.

Množenjem vektor retka $\mathbf{v}^{\mathrm{T}}$ koji sadrži elemente koeficijenata bruto dodane vrijednosti, te koji je dimenzije 1 x 64, s inverznom Leontijevljevom matricom (reda 64 x 64) dobiva se vektor redak (1 x 64). Množenjem umnoška $\mathbf{v}^{\mathrm{T}}\left(\mathbf{I}-\mathbf{A}^{\mathbf{D}}\right)^{-1}$ i vektor stupaca finalne potrošnje koji su dimenzije 64 x 1 dobiva se ukupni BDV koji je rezultat proizvodnih aktivnosti poduzetih radi isporuka dobara i usluga sektorima nositeljima finalne potražnje. Ukoliko je predmet analize ne samo ukupni BDV koji je vezan uz finalne isporuke, već i strukturne karakteristike, odnosno vrijednost outputa raščlanjena po proizvodnim sektorima, potrebno je umjesto vektor retka $\mathbf{v}^{\mathrm{T}}$ u izračunu koristiti matricu $\operatorname{diag}\left(\mathbf{v}^{\mathrm{T}}\right)$ u kojoj su elementi glavne dijagonale input-output koeficijenti bruto dodane vrijednosti, a ostale vrijednosti su 0 . U tom slučaju ukupni rezultat nije samo jedan podatak (ukupni BDV), već vektor stupac dimenzije 64 x 1 čiji su elementi vrijednosti bruto dodane vrijednosti svakog proizvodnog sektora koje su rezultat isporuke dobara i usluga za zadovoljenje finalne potražnje za proizvodima domaćeg podrijetla.

U tom slučaju se jednadžbe transformiraju u:

$$
\begin{aligned}
& \mathbf{v}_{\mathbf{C}}=\operatorname{diag}(\mathbf{v})\left(\mathbf{I}-\mathbf{A}^{\mathrm{D}}\right)^{-1} \mathbf{c}^{\mathbf{D}}, \\
& \mathbf{v}_{\mathbf{G}}=\operatorname{diag}(\mathbf{v})\left(\mathbf{I}-\mathbf{A}^{\mathrm{D}}\right)^{-1} \mathbf{g}^{\mathbf{D}},
\end{aligned}
$$




$$
\begin{aligned}
& \mathbf{v}_{\mathbf{I}}=\operatorname{diag}(\mathbf{v})\left(\mathbf{I}-\mathbf{A}^{\mathrm{D}}\right)^{-1} \mathbf{i}^{\mathbf{D}}, \\
& \mathbf{v}_{\mathbf{E}}=\operatorname{diag}(\mathbf{v})\left(\mathbf{I}-\mathbf{A}^{\mathrm{D}}\right)^{-1} \mathbf{e}^{\mathbf{D}} .
\end{aligned}
$$

Oznaka v (malo podebljano slovo) označava da je riječ o vektor retku koji prikazuje raspodjelu bruto dodane vrijednosti po proizvodnim sektorima, dok oznaka V (veliko slovo) kao u slučaju gore navedenih jednadžbi upućuje na ukupnu vrijednost BDV-a (brojčana vrijednost, dimenzija 1 x 1).

Vektor stupci $\mathbf{v}_{\mathbf{C}}, \mathbf{v}_{\mathbf{G}}, \mathbf{v}_{\mathbf{I}} \mathbf{i} \mathbf{v}_{\mathbf{E}}$ (dimenzije $64 \times 1$ ) se predmnoženjem sa sumarnim vektorom i, čiji su elementi odgovarajući broj vrijednosti 1 (u konkretnom slučaju vektor redak dimenzije 1 x 64), svode na ukupnu bruto dodanu vrijednost označenu s $\mathrm{V}_{\mathrm{C}}, \mathrm{V}_{\mathrm{G}}, \mathrm{V}_{\mathrm{I}}$ i $\mathrm{V}_{\mathrm{E}}$.

Osim bruto proizvodnje i bruto dodane vrijednosti, korištenjem input-output metodologije može se raščlaniti i ukupan broj zaposlenih osoba koji je izravno i neizravno potreban u proizvodnim procesima poduzetima za zadovoljenje pojedine sastavnice finalne potražnje za domaćim dobrima i uslugama. U tom slučaju, umjesto input-output koeficijenata za dodanu vrijednost, koriste se input-output koeficijenti za zaposlenost (e) koji prikazuju koliko je zaposlenih osoba potrebno u svakom proizvodnom sektoru za proizvodnju jedinične vrijednosti outputa.

$$
\begin{aligned}
& \mathrm{E}=\mathrm{E}_{\mathrm{C}+} \mathrm{E}_{\mathrm{G}+} \mathrm{E}_{\mathrm{I}+} \mathrm{E}_{\mathrm{E},} \\
& \mathrm{E}_{\mathrm{C}}=\mathbf{e}^{\mathrm{T}}\left(\mathbf{I}-\mathbf{A}^{\mathrm{D}}\right)^{-1 *} \mathbf{c}^{\mathrm{D}}, \\
& \mathrm{E}_{\mathrm{G}}=\mathbf{e}^{\mathrm{T}}\left(\mathbf{I}-\mathbf{A}^{\mathrm{D}}\right)^{-1 *} \mathbf{g}^{\mathrm{D}}, \\
& \mathrm{E}_{\mathrm{I}}=\mathbf{e}^{\mathrm{T}}\left(\mathbf{I}-\mathbf{A}^{\mathrm{D}}\right)^{-1 * \mathbf{i}^{\mathrm{D}},} \\
& \mathrm{E}_{\mathrm{E}}=\mathbf{e}^{\mathrm{T}}\left(\mathbf{I}-\mathbf{A}^{\mathrm{D}}\right)^{-1 *} \mathbf{e}^{\mathrm{D}} .
\end{aligned}
$$

Input-output koeficijenti za zaposlenost $\left(\mathbf{e}^{\mathrm{T}}\right)$ prikazani su vektor retkom (reda 1 x 64). Množenjem vektor retka s Leontijevljevom matricom $\left(\mathbf{I}-\mathbf{A}^{\mathbf{D}}\right)^{-1}$ koja je reda 64 x 64 dobiva se vektor redak (1 x 64), koji množenjem s vektor stupcem pojedine sastavnice finalne potražnje (dimenzije 64 x 1) rezultira samo ukupnom zaposlenošću koja je potrebna za zadovoljenje pojedine sastavnice finalne potražnje (oznaka E, matrica dimenzije $1 \times 1$ ). Ukoliko se vektor redak e transformira u matricu diag(e), čiji su elementi na glavnoj dijagonali input-output koeficijenti za zaposlenost (broj zaposlenih po jedinici outputa za svaki proizvodni sektor), tada je rezultat množenja vektor stupac čiji su elementi brojevi zaposlenih po proizvod- 
nim sektorima koje je potrebno angažirati za zadovoljenje pojedine komponente finalne potražnje.

U tom slučaju se jednadžbe transformiraju u:

$$
\begin{aligned}
& \mathbf{e}_{\mathbf{C}}=\operatorname{diag}(\mathbf{e})\left(\mathbf{I}-\mathbf{A}^{\mathrm{D}}\right)^{-1} \mathbf{c}^{\mathbf{D}}, \\
& \mathbf{e}_{\mathbf{G}}=\operatorname{diag}(\mathbf{e})\left(\mathbf{I}-\mathbf{A}^{\mathrm{D}}\right)^{-1} \mathbf{g}^{\mathbf{D}}, \\
& \mathbf{e}_{\mathbf{I}}=\operatorname{diag}(\mathbf{e})\left(\mathbf{I}-\mathbf{A}^{\mathrm{D}}\right)^{-1} \mathbf{i}^{\mathbf{D}}, \\
& \mathbf{e}_{\mathbf{E}}=\operatorname{diag}(\mathbf{e})\left(\mathbf{I}-\mathbf{A}^{\mathrm{D}}\right)^{-1} \mathbf{e}^{\mathbf{D}} .
\end{aligned}
$$

Vektor stupci $\mathbf{e}_{\mathrm{C}}, \mathbf{e}_{\mathrm{G}}, \mathbf{e}_{\mathbf{I}}$ i $\mathbf{e}_{\mathbf{E}}$ (dimenzije $64 \times 1$ ) se predmnoženjem sa sumarnim vektorom i, čiji su elementi odgovarajući broj vrijednosti 1 (u konkretnom slučaju vektor redak dimenzije 1 x 64), mogu svesti na ukupnu zaposlenost označenu $\mathrm{s} \mathrm{E}_{\mathrm{C}}, \mathrm{E}_{\mathrm{G}}, \mathrm{E}_{\mathrm{I}}$ i $\mathrm{E}_{\mathrm{E}}$.

Porast finalne potražnje osim utjecaja na domaću proizvodnju ima učinak i na porast uvoza. Izravni uvoz svake od sastavnica finalne potražnje prikazan je vektor stupcima koji prikazuju finalnu potražnju zadovoljenu dobrima i uslugama uvoznog podrijetla: $\mathbf{f}^{\mathrm{U}}=\mathbf{C}^{\mathrm{U}}+\mathbf{G}^{\mathrm{U}}+\mathbf{I}^{\mathrm{U}}+\mathbf{E}^{\mathrm{U}}$. Riječ je o vektor stupcima čiji elementi sadrže uvoz svake od sastavnica distribuiran na dobra i usluge svrstane u različite skupine proizvoda (u konkretnom slučaju riječ je o 64 sektora, odnosno vektor stupcu dimenzije 64 x 1). Zbroj uvoza svih proizvoda i usluga koji služe izravnom zadovoljenju određene komponente finalne potražnje prikazuje ukupnu uvoznu zavisnost pojedine kategorije finalne potražnje.

Osim izravne uvozne zavisnosti, ukupan uvoz dobara i usluga za pojedinu sastavnicu finalne potražnje obuhvaća i neizravnu uvoznu zavisnost koja proizlazi iz potrebe domaćih proizvođača za nabavom uvoznih dobara i usluga za svoje proizvodne procese. Vrijednost indirektnog uvoza koji je potreban za zadovoljenje finalne potražnje korištenjem input-output modela izračunava se predmnoženjem vrijednosti domaće proizvodnje koja je isporučena za finalnu potražnju (umnožak $\left.\left(\mathbf{I}-\mathbf{A}^{\mathrm{D}}\right)^{-1} \mathbf{f}^{\mathrm{D}}\right)$ s vektor retkom koji prikazuje koeficijente ukupnih uvoznih inputa svakog od domaćih proizvodnih sektora $\left(\mathbf{u}^{\mathrm{T}}\right)$, odnosno udio uvoznih intermedijarnih inputa u vrijednosti proizvodnje domaćih sektora. Tako je neizravni uvoz potreban za zadovoljenje domaće potražnje jednak:

$$
\begin{aligned}
& \mathrm{U}_{\mathrm{C}}=\mathbf{u}^{\mathrm{T}}\left(\mathbf{I}-\mathbf{A}^{\mathrm{D}}\right)^{-1 *} \mathbf{c}^{\mathrm{D}}, \\
& \mathrm{U}_{\mathrm{G}}=\mathbf{u}^{\mathrm{T}}\left(\mathbf{I}-\mathbf{A}^{\mathrm{D}}\right)^{-1 *} \mathbf{g}^{\mathrm{D}},
\end{aligned}
$$




$$
\begin{aligned}
& \mathrm{U}_{\mathrm{I}}=\mathbf{u}^{\mathrm{T}}\left(\mathbf{I}-\mathbf{A}^{\mathrm{D}}\right)^{-1 * \mathbf{i}^{\mathrm{D}},} \\
& \mathrm{U}_{\mathrm{E}}=\mathbf{u}^{\mathrm{T}}\left(\mathbf{I}-\mathbf{A}^{\mathrm{D}}\right)^{-1 *} \mathbf{e}^{\mathrm{D}} .
\end{aligned}
$$

Ukoliko je predmet analize ne samo ukupna izravna i neizravna uvozna zavisnost, već i struktura uvoza po pojedinim proizvodnim sektorima, tada je potrebno matricu ukupnih potreba za uvozom pomnožiti s određenom sastavnicom finalne potražnje, te je:

$$
\begin{aligned}
& \mathbf{u}_{\mathbf{C}}=\operatorname{diag}(\mathbf{u})\left(\mathbf{I}-\mathbf{A}^{\mathrm{D}}\right)^{-1} \mathbf{c}^{\mathbf{D}}, \\
& \mathbf{u}_{\mathrm{G}}=\operatorname{diag}(\mathbf{u})\left(\mathbf{I}-\mathbf{A}^{\mathrm{D}}\right)^{-1} \mathbf{g}^{\mathbf{D}}, \\
& \mathbf{u}_{\mathbf{I}}=\operatorname{diag}(\mathbf{u})\left(\mathbf{I}-\mathbf{A}^{\mathrm{D}}\right)^{-1} \mathbf{i}^{\mathbf{D}}, \\
& \mathbf{u}_{\mathbf{E}}=\operatorname{diag}(\mathbf{u})\left(\mathbf{I}-\mathbf{A}^{\mathrm{D}}\right)^{-1} \mathbf{e}^{\mathbf{D}} .
\end{aligned}
$$

Kako je u metodološkom dijelu definirano, matrica $\mathbf{A}^{\mathrm{U}}$ prikazuje izravne potrebe pojedinih sektora za uvozom određenih skupina dobara i usluga. Na isti način kao i inverzna Leontijevljeva matrica za domaću uporabu, i matrica $\mathbf{u}^{\mathrm{T}}(\mathbf{I}$ $\left.-\mathbf{A}^{\mathrm{D}}\right)^{-1}$ prikazuje ukupne izravne i neizravne potrebe domaćih proizvođača za intermedijarnim proizvodima uvoznog podrijetla. Množenjem matrica $\mathbf{A}^{\mathrm{U}}\left(\mathbf{I}-\mathbf{A}^{\mathrm{D}}\right)^{-1} \mathrm{i}$ određene komponente finalne potražnje dobivaju se indirektne potrebe za uvoznim proizvodima za tu kategoriju potražnje raščlanjene na $n$ skupina dobara i usluga (u konkretnom slučaju riječ je o 64 skupine proizvoda). Ukupne indirektne potrebe za uvozom Uc dobivaju se zbrajanjem elemenata vektor stupca $\mathbf{u}_{\mathrm{c}}$, odnosno, $\mathrm{u}$ terminima matrične algebre, predmnoženjem s vektor retkom i čiji su elementi jedinice:

$$
\begin{aligned}
& \mathrm{U}_{\mathrm{C}}=\mathbf{i} \mathbf{u}_{\mathrm{c}}, \\
& \mathrm{U}_{\mathrm{G}}=\mathbf{i} \mathbf{u}_{\mathrm{G}}, \\
& \mathrm{U}_{\mathrm{I}}=\mathbf{i} \mathbf{u}_{\mathrm{I}}, \\
& \mathrm{U}_{\mathrm{E}}=\mathbf{i} \mathbf{u}_{\mathrm{E}} .
\end{aligned}
$$

Ukupni uvoz potreban za zadovoljenje finalne potražnje stoga ima dvije sastavnice: izravnu, koja se odnosi na uvozne proizvode i usluge koje nositelji finalne 
potrošnje koriste bez transformacije $\left(\mathrm{C}^{\mathrm{U}}, \mathrm{G}^{\mathrm{U}}, \mathrm{I}^{\mathrm{U}}, \mathrm{E}^{\mathrm{U}}\right)$, te neizravnu komponentu koja se odnosi na intermedijarne proizvode i usluge uvoznog podrijetla koji su ugrađeni u finalne proizvode domaćih proizvođača $\left(\mathrm{U}_{\mathrm{C}}, \mathrm{U}_{\mathrm{G}}, \mathrm{U}_{\mathrm{I}} \mathrm{i} \mathrm{U}_{\mathrm{E}}\right)$.

Ukupna finalna potražnja u input-output modelu na gore prikazani način stoga određuje sve ostale makroekonomske kategorije: domaću proizvodnju (x), domaću i uvoznu intermedijarnu potrošnju (u), ukupan uvoz, bruto dodanu vrijednost (v) i zaposlenost. Korištenjem input-output modela svaka od makroekonomskih kategorija, kako na razini ukupnog gospodarstva, tako i po sektorima, može se dekomponirati na dijelove koji su vezani uz točno određenu komponentu finalne potražnje.

Simetrične input-output tablice se izrađuju u bazičnim cijenama, te i svi gore navedeni koncepti izračunati primjenom input-output modela također odražavaju isti koncept vrednovanja za sve kategorije. Međutim, temeljem podataka iz simetričnih input-output tablica mogu se transformirati i vrijednosti iz koncepta bazičnih cijena u tržišne kupovne cijene, na način da se makroekonomski agregati dodavanjem neodbitnih poreza na proizvode (umanjenih za subvencije na proizvode) transformiraju u koncept kupovnih cijena. Input-output tablice sadrže dodatni korektivni redak za koncept vrednovanja koji prikazuje neodbitne neto poreze na proizvode, odnosno udio poreza umanjenih za subvencije za sve kategorije finalne i intermedijarne potrošnje. U većini europskih zemalja sustav oporezivanja dobara i usluga primarno je vezan uz finalnu potražnju. Ipak, određeni udio neodbitnih poreza sadržan je i u intermedijarnoj potrošnji proizvodnih sektora. Riječ je o PDV-u na nabave proizvođačkih jedinica koje nisu uključene u sustav PDV-a te određenim neodbitnim porezima koje plaćaju sve jedinice bez obzira koriste li se proizvodi za finalnu ili intermedijarnu namjenu. Neodbitni porezi najčešće obuhvaćaju trošarine, odnosno posebne poreze na određeni skup proizvoda.

Neodbitni porezi u simetričnim input-output tablicama objavljuju se samo na razini ukupnog udjela svakog od proizvodnih sektora, odnosno sastavnica finalne potražnje. Stoga se transformacija komponenti iz bazičnih u tržišne cijene može iskazati samo na razini ukupne sastavnice, a ne i raščlanjenu po dobrima i uslugama. $C^{\text {tind }}$ jest vrijednost neto poreza na proizvode koji se izravno naplaćuju na osobnu potrošnju, a ista oznaka kategorije s eksponentom ${ }^{\text {tind }}$ vrijedi i za sve ostale kategorije finalne potražnje.

Udio neodbitnih poreza na intermedijarne inpute u ukupnoj vrijednosti bruto proizvodnje pojedinih sektora označen je s tind (vektor redak sa 64 elementa). Na isti način kao i kod ostalih makroekonomskih agregata, predmnoženjem ukupne domaće proizvodnje koja je potrebna za isporuku dobara i usluga za određenu kategoriju finalne potražnje s vektor retkom udjela neodbitnih indirektnih poreza, može se izračunati iznos neodbitnih neto poreza sadržanih u intermedijarnoj potrošnji domaćih proizvodnih sektora i raspodijeliti ih na sastavnice finalne potražnje. 


$$
\begin{aligned}
& \operatorname{TIND}_{\mathrm{C}}=\operatorname{tind}^{\mathrm{T}}\left(\mathbf{I}-\mathbf{A}^{\mathrm{D}}\right)^{-1 *} \mathbf{c}^{\mathrm{D}}, \\
& \operatorname{TIND}_{\mathrm{G}}=\operatorname{tind}^{\mathrm{T}}\left(\mathbf{I}-\mathbf{A}^{\mathrm{D}}\right)^{-1 *} \mathbf{g}^{\mathrm{D}}, \\
& \operatorname{TIND}_{\mathrm{I}}=\operatorname{tind}^{\mathrm{T}}\left(\mathbf{I}-\mathbf{A}^{\mathrm{D}}\right)^{-1 * \mathbf{i}^{\mathrm{D}},} \\
& \operatorname{TIND}_{\mathrm{E}}=\operatorname{tind}^{\mathrm{T}}\left(\mathbf{I}-\mathbf{A}^{\mathrm{D}}\right)^{-1 *} \mathbf{e}^{\mathrm{D}} .
\end{aligned}
$$

Ukupni neodbitni porezi za pojedinu sastavnicu finalne potražnje jednaki su zbroju neto neizravnih poreza sadržanih u pojedinoj komponenti finalne potražnje $\left(C^{\text {tind }}, G^{\text {tind }} I^{\text {tind }}, E^{\text {tind }}\right)$ i neto neodbitnih neizravnih poreza sadržanih u intermedijarnoj potrošnji proizvodnih sektora koji proizvode $\mathrm{i}$ isporučuju dobra za intermedijarnu potrošnju $\left(\right.$ TIND $_{C}$, TIND $_{G}$, TIND $\left._{I} i_{\text {TIND }}\right)$.

Uključivanjem neto poreza na dobra i usluge postiže se konzistentnost sa standardnim skupom podataka koji statistički uredi objavljuju prilikom objave podataka o ukupno ostvarenom bruto domaćem proizvodu, u kojem su sastavnice potražne strane uobičajeno objavljene prema konceptu kupovnih cijena.

Empirijski izračun u sljedećem poglavlju temelji se na input-output tablici za 2013. godinu (Mikulić, 2018). Službena input-output tablica za 2010. godinu (Državni zavod za statistiku 2015), u kategoriju izdataka kućanstava za finalnu potrošnju agregira izdatke rezidentnih i nerezidentih kućanstava (potrošnja turista), te u određenoj mjeri iskrivljuje pojedinačne učinke domaće i inozemne potražnje.

\section{Rezultati - dekompozicija BDP-a na sastavnice finalne potražnje za Republiku Hrvatsku}

Primjenom opisane metodologije dekompozicije i input-output tablice za 2013. godinu moguće je utvrditi za svaki sektor, odnosno za ukupno gospodarstvo udio bruto dodane vrijednosti i zaposlenosti koji je induciran pojedinom sastavnicom finalne potražnje. Svaka komponenta finalne potražnje ima specifičnu kombinaciju dobara i usluga po različitim sektorima nacionalnog gospodarstva, a time i različite multiplikativne učinke. Ukupni iznos potražnje u tržišnim cijenama raspodjeljuje se na neto poreze na proizvode te potražnju u bazičnim cijenama. Potražnja u bazičnim cijenama nadalje je razdvojena na potražnju za dobrima i uslugama uvoznog podrijetla (izravni uvoz) te potražnju za proizvodima domaćih sektora. Potražnja za domaćim proizvodima utječe na pojavu multiplikativnih učinaka na domaću proizvodnju, BDV i zaposlenost. 
Tablica 1. prikazuje strukturu finalne potražnje i učinke na bruto dodanu vrijednost i zaposlenost hrvatskog gospodarstva u 2013. godini. Ukupna finalna potražnja u tržišnim cijenama iznosila je oko 473 milijarde HRK, od čega je najznačajniji udio izdataka za finalnu potrošnju kućanstava koji iznosi 41,7 posto. Druga najznačajnija sastavnica finalne potražnje je izvoz koji obuhvaća i izvoz usluga, dok je udio potrošnje države i investicija u fiksni kapital i povećanje zaliha nešto manji i iznosi 13,3 posto (investicije), odnosno 14 posto (izdaci za finalnu potrošnju države).

\section{Tablica 1.}

\section{DEKOMPOZICIJA BRUTO DODANE VRIJEDNOSTI I ZAPOSLENOSTI NA POJEDINE SASTAVNICE FINALNE POTRAŽNJE}

\begin{tabular}{|l|r|r|r|r|r|}
\hline & $\begin{array}{c}\text { Potrošnja } \\
\text { kućanstava i } \\
\text { NPUSK-a }\end{array}$ & $\begin{array}{c}\text { Potrošnja } \\
\text { države }\end{array}$ & Investicije & Izvoz & Ukupno \\
\hline Ukupna finalna potražnja & 197.470 & 66.151 & 62.976 & 146.691 & 473.288 \\
\hline Neto neodbitni porezi & 30.723 & 93 & 1.194 & 9.763 & 41.773 \\
\hline Izravan uvoz & 29.521 & 2.100 & 14.805 & 32.956 & 79.382 \\
\hline $\begin{array}{l}\text { Potražnja za dobrima i uslugama } \\
\text { domaćih proizvođača }\end{array}$ & 137.225 & 63.959 & 46.978 & 103.972 & 352.133 \\
\hline $\begin{array}{l}\text { Ukupni domaći output u lancu } \\
\text { dodane vrijednosti (izravan i } \\
\text { neizravan) }\end{array}$ & 213.871 & 92.565 & 83.767 & 173.150 & 563.353 \\
\hline Multiplikator outputa & 1,56 & 1,45 & 1,78 & 1,67 & 1,60 \\
\hline $\begin{array}{l}\text { Ukupni BDV u lancu dodane } \\
\text { vrijednosti }\end{array}$ & 111.695 & 53.169 & 35.109 & 77.832 & 277.805 \\
\hline $\begin{array}{l}\text { Ukupna zaposlenost u lancu } \\
\text { dodane vrijednosti }\end{array}$ & 533 & 331 & 212 & 456 & 1.532 \\
\hline \multicolumn{7}{|c|}{ Udio sastavnice finalne potražnje u ukupnoj kategoriji } \\
\hline Ukupna finalna potražnja & 41,7 & 14,0 & 13,3 & 31,0 & 100,0 \\
\hline Neto neodbitni porezi & 73,5 & 0,2 & 2,9 & 23,4 & 100,0 \\
\hline Izravan uvoz & 37,2 & 2,6 & 18,6 & 41,5 & 100,0 \\
\hline $\begin{array}{l}\text { Potražnja za dobrima i uslugama } \\
\text { domaćih proizvođača }\end{array}$ & 39,0 & 18,2 & 13,3 & 29,5 & 100,0 \\
\hline $\begin{array}{l}\text { Ukupni domaći output u lancu } \\
\text { dodane vrijednosti }\end{array}$ & 38,0 & 16,4 & 14,9 & 30,7 & 100,0 \\
\hline Ukupni BDV & 40,2 & 19,1 & 12,6 & 28,0 & 100,0 \\
\hline Ukupna zaposlenost & 34,8 & 21,6 & 13,8 & 29,8 & 100,0 \\
\hline
\end{tabular}

Izvor: Izračun autora. 
Porezni sustav RH oslonjen je primarno na oporezivanje finalne potrošnje, te se gotovo tri četvrtine neodbitnih poreza na proizvode odnosi na ovu kategoriju. Određeni udio finalne potražnje zadovoljava se dobrima i uslugama uvoznog podrijetla. Zanimljivo je primijetiti da je udio izravnog uvoza u kategoriji investicija značajno viši od udjela ove kategorije u ukupnoj finalnoj potražnji, što upućuje na visoku ovisnost ove kategorije o izravnom uvozu strojeva i opreme. Uvozna ovisnost je posljedica nedovoljne tehnološke razvijenosti domaćeg gospodarstva i nemogućnosti proizvodnje složenijih investicijskih proizvoda. U kategoriji izvoza dobara i usluga također je udio izravnog uvoza viši od udjela kategorije u ukupnoj finalnoj potražnji. To je posljedica reeksporta, odnosno povoljne geografske pozicije Hrvatske i distribucijskih kanala međunarodne razmjene u koje su uključeni domaći poduzetnici, što se posebice intenziviralo uslijed pridruživanja Europskoj uniji. Osim reeksporta dobara, drugi dio uvoznog sadržaja u izvozu usluga odnosi se na potrošnju stranih turista u Hrvatskoj, koji prilikom boravka u Hrvatskoj pored hrvatskih proizvoda kupuju i inozemna dobra koja uobičajeno nabavljaju u svojim domicilnim zemljama.

Finalna potražnja za domaćim proizvodima odražava se na izravne prihode domaćih jedinica, a jednaka je razlici između ukupnih finalnih izdataka te zbroja neto poreza na proizvode $\mathrm{i}$ vrijednosti uvoznih dobara koja se izravno koriste $\mathrm{u}$ finalnoj potrošnji. Najznačajniji utjecaj na domaću proizvodnju imaju izdaci za finalnu potrošnju kućanstava. Prihodi poduzetnika u bazičnim cijenama za dobra i usluge isporučene kućanstvima iznosili su 2013. godine oko 137 milijardi HRK od ukupno 352 milijarde HRK finalnih isporuka. Da bi se isporučila tražena vrijednost finalnih dobara i usluga, domaći proizvođači nabavljaju intermedijarna dobra i usluge od ostalih domaćih i inozemnih dobavljača, te je ukupni output svih domaćih jedinica uključenih u lanac dodane vrijednosti izravnih isporučitelja dobara i usluga sektoru kućanstava iznosio oko 214 milijardi HRK, odnosno multiplikator outputa je bio 1,56.

Kao što se može vidjeti iz rezultata prikazanih u tablici 1., multiplikator outputa najveći je za kategoriju investicijskih dobara i izvoza. Visoki multiplikator je rezultat složenijih proizvoda te dubljeg lanca dodane vrijednosti i raznovrsnijih intermedijarnih inputa koji se koriste u proizvodnji investicijskih dobara. Naime, tehnologija proizvodnje investicijskih proizvoda zahtijeva primjenu procesa proizvodnje više tehnološke razine i složenosti, te je u pravilu u lanac dodane vrijednosti uključeno više proizvođača. S druge strane, dobra i usluge koja koriste kućanstva u prosjeku su manje tehnološke složenosti (visok udio jednostavnih usluga) i stoga su i multiplikativni učinci na ostale jedinice nižeg intenziteta.

Na razini ukupnog hrvatskog gospodarstva može se zaključiti da izdaci za finalnu potrošnju kućanstava imaju dominantan utjecaj na ukupnu bruto dodanu vrijednost i zaposlenost. Od ukupno 278 milijardi HRK bruto dodane vrijednosti, 
oko 40 posto, odnosno oko 112 milijardi HRK vezano je uz isporuke dobara i usluga sektoru kućanstava za finalnu potrošnju, a u cijelom lancu dobavljača proizvoda za finalnu potrošnju kućanstava zaposleno je 533 tisuće osoba. Izvoz dobara i usluga izravno i neizravno je zaslužan za 456 tisuća radnih mjesta, te ove dvije kategorije zajedno generiraju oko dvije trećine ukupne bruto dodane vrijednosti i zaposlenosti u Hrvatskoj. Izdaci za državnu potrošnju obuhvaćaju u najvećoj mjeri uslužne djelatnosti poput javne uprave, obrazovanja i zdravstva. Navedeni sektori imaju nešto manje izražene multiplikativne učinke, ali su radnointenzivni što objašnjava veći udio ove kategorije u zaposlenosti u usporedbi s vrijednosti isporuka i bruto dodane vrijednosti. U 2013. godini oko 330 tisuća radnih mjesta bilo je generirano izdacima za državnu potrošnju, što obuhvaća zaposlenike u državnim jedinicama, ali i proizvođačima koji isporučuju dobra i usluge namijenjene intermedijarnoj potrošnji državnih jedinica.

Najmanje zaposlenih osoba radno mjesto osigurava u lancu dodane vrijednosti proizvođača investicijskih dobara i usluga. Na prvi pogled je iznenađujuće da je udio zaposlenosti niži od udjela u BDV-u u lancu isporučitelja dobara i usluga kućanstvima, što bi upućivalo na iznadprosječnu produktivnost u tom dijelu gospodarstva. Dio objašnjenja leži u činjenici da određene imputirane kategorije koje su uključene u finalnu potrošnju kućanstava prema metodologiji nacionalnih računa ne podrazumijevaju input rada (imputirana stambena renta) ili input rada nije na odgovarajući način zabilježen u službenim podacima o broju zaposlenih u određenim kategorijama neformalnog rada, poput poljoprivredne proizvodnje za vlastitu potrošnju ili nelegalnih aktivnosti.

Svaki od proizvodnih sektora nacionalnog gospodarstva ostvaruje bruto dodanu vrijednost koja se može dekomponirati na određenu sastavnicu finalne potražnje, bilo da sektor izravno isporučuje dobra i usluge određenom finalnom potrošaču ili je uključen u lanac dodane vrijednosti putem isporuke intermedijarnih proizvoda koja je potrebna za proizvodnju i isporuku finalnih dobara i usluga. Ovisno o karakteristikama dobara i usluga koje proizvode, sektori su heterogeni u pogledu utjecaja različitih sektora finalne potražnje. Tako je u određenim sektorima, poput imputiranih stambenih usluga ili usluga pomoćnog osoblja u kućanstvima, cjelokupna ostvarena dodana vrijednost ovisna o osobnoj potrošnji kućanstava (Slika 1). 


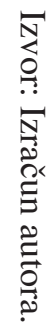

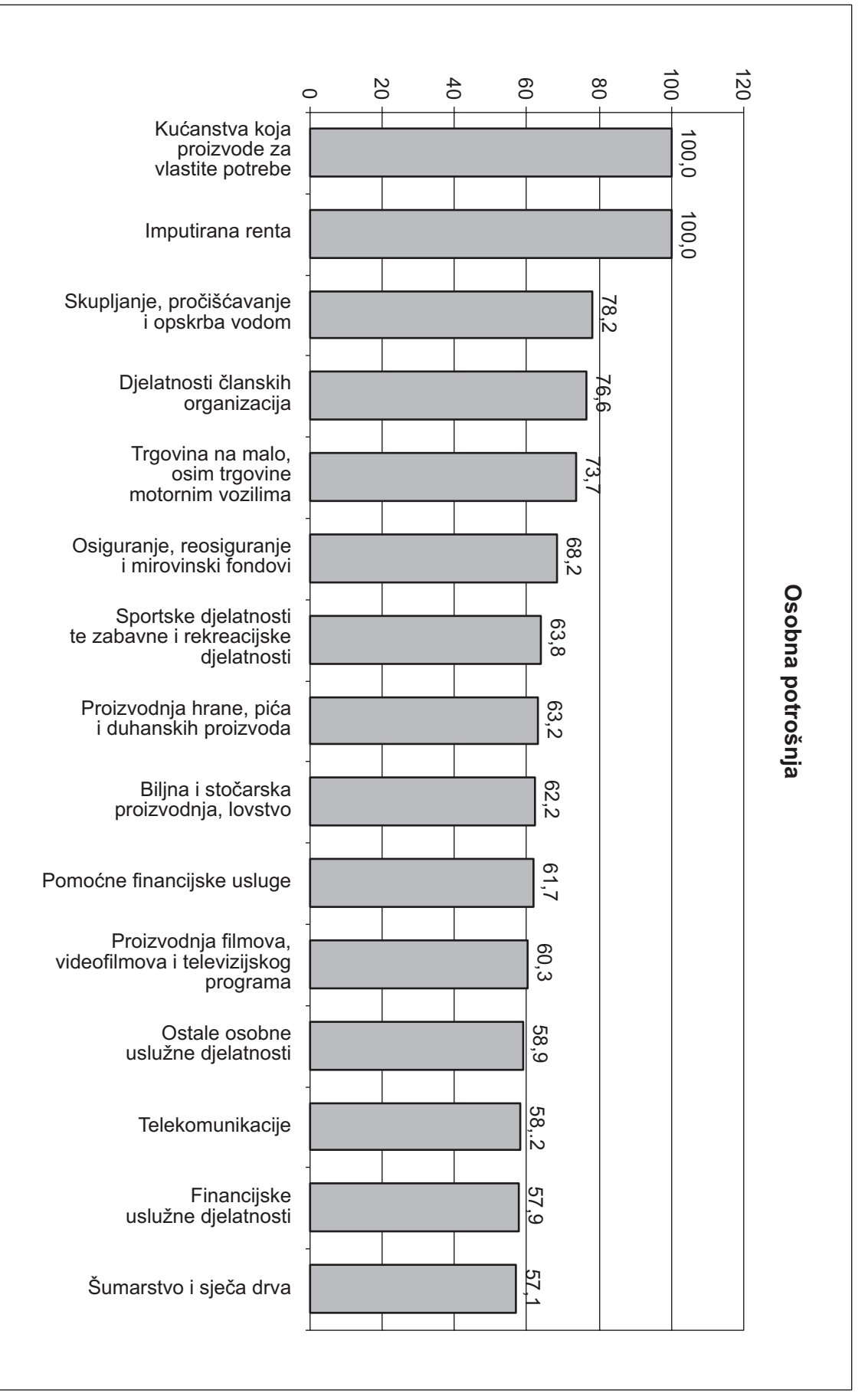

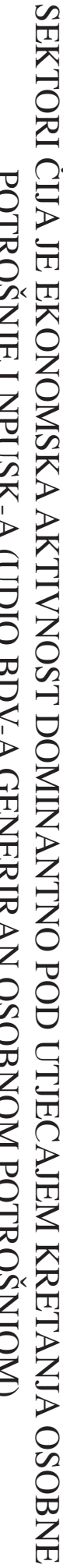

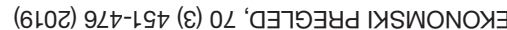

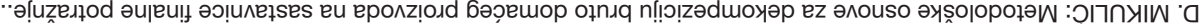



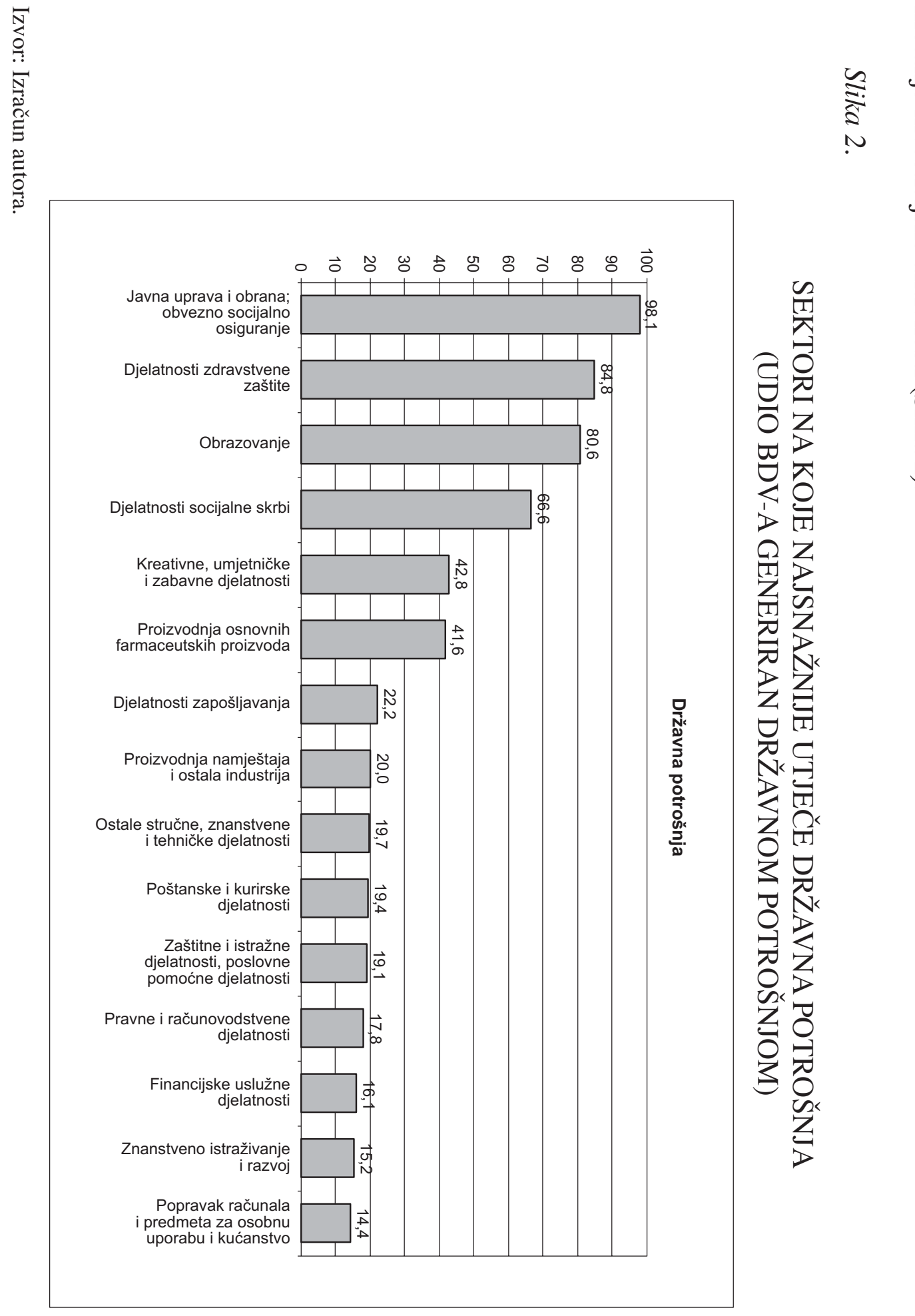

त्र

壳.

苛恕

¿

․ㅠ

등

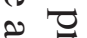

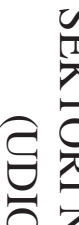

궁

Javna uprava i obrana; osiguranje

E.

ㅇํㅇ

$\stackrel{2}{\rightleftarrows}$

थ

$\forall$ त्र

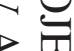

Q Z

픈

II

$\underset{N}{D}$

Z

$\forall$ II

$\underset{ }{\nabla}$

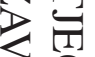

$Z \hat{x}$

$\underset{\sigma}{\sigma}$

$\checkmark N$

韦

W $D$

Z

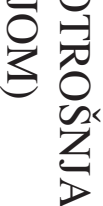

हैं

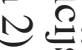

2

อิ

등

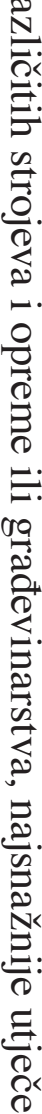


गี่

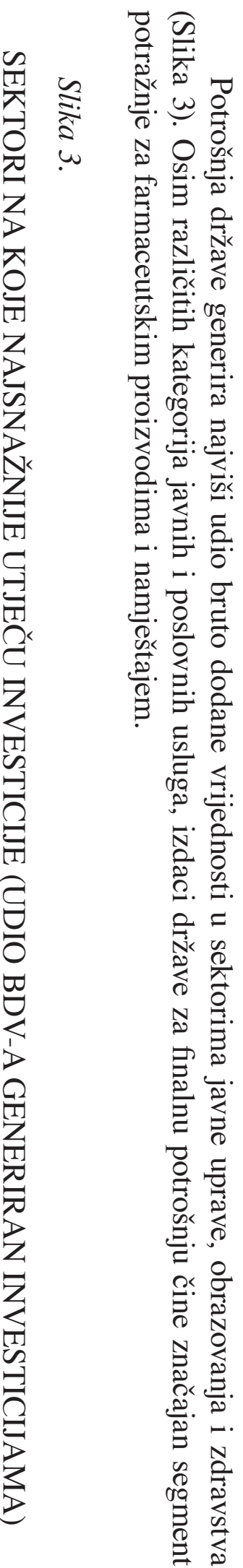

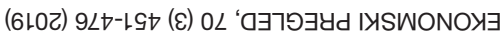

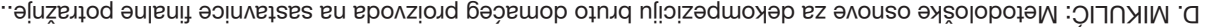


D. MIKULIĆ: Metodološke osnove za dekompeziciju bruto domaćeg proizvoda na sastavnice finalne potražnje...

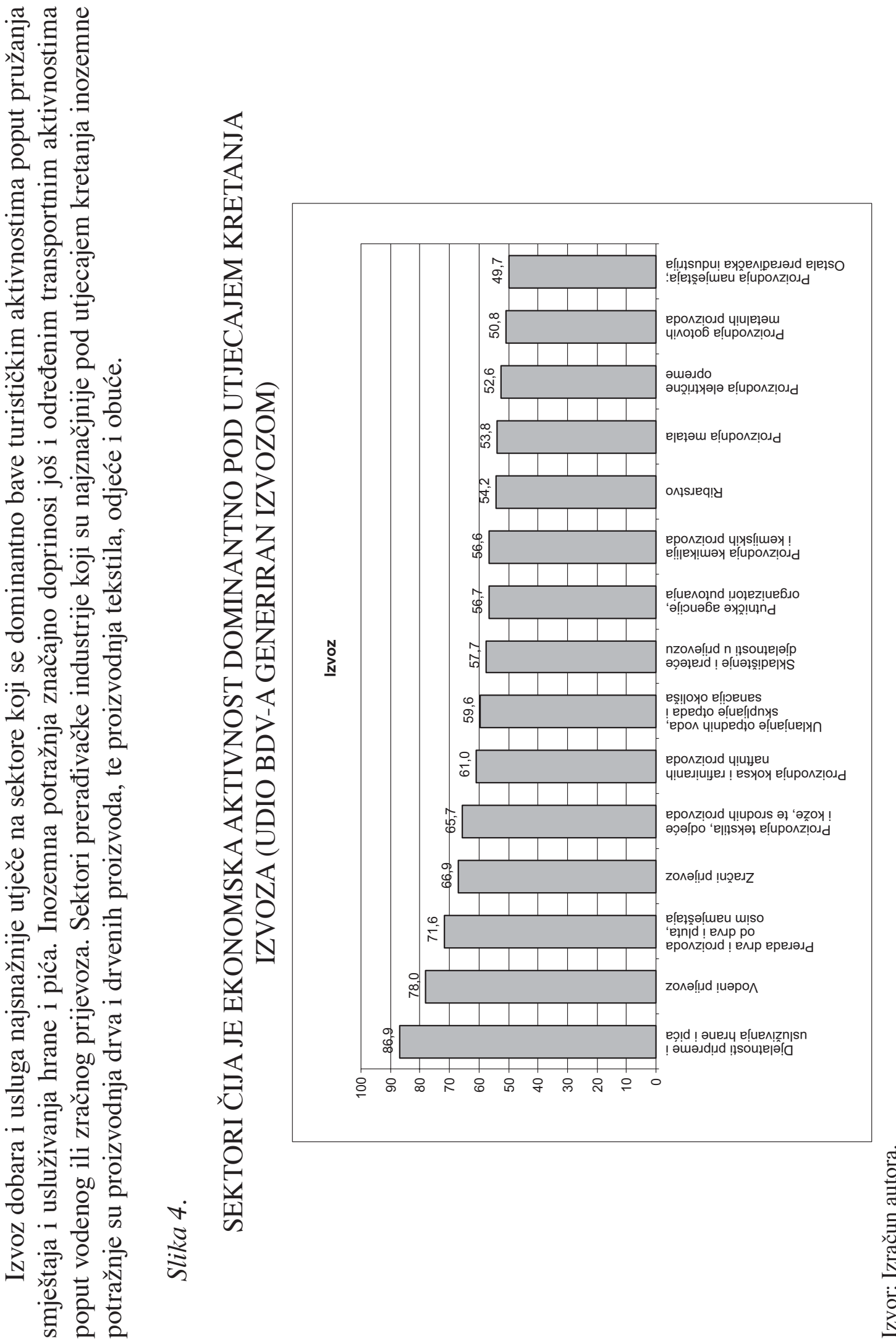


Učinak svake sastavnice finalne potražnje na sektore na koje ona najznačajnije utječe grafički prikazan slikama 1. do 4. Determinante kretanja finalne potražnje različite su za svaku od sastavnica. Kretanje osobne potrošnje vezano je uz sadašnji i očekivani dohodak u budućem razdoblju, izvoz ovisi o kretanju dohodaka u zemljama partnerima i tečaju, investicije o razini kamata i očekivane potražnje, dok je državna potrošnja uglavnom vezana uz ciljeve i mjere ekonomske politike. Promjena svakog od ovih parametara utječe na ukupnu razinu pojedine sastavnice, a time i na gospodarsku aktivnost sektora koji izravno ili neizravno sudjeluju u proizvodnji i isporuci finalnih dobara i usluga.

Promjena svake od sastavnica finalne potražnje, osim na izravne isporučitelje, ima utjecaj i na kretanje gospodarske aktivnosti i zaposlenosti u sektorima koji su uključeni u proizvodni lanac izravnih isporučitelja. Tako je, primjerice, u djelatnosti biljne i stočarske proizvodnje od ukupno 129 tisuća zaposlenika čak 80 tisuća vezano uz proizvodni lanac koji isporučuje dobra i usluge za osobnu potrošnju kućanstava. Rezultati pokazuju da čak 40 tisuća zaposlenih osoba u poljoprivredi proizvode dobra koja izravno ili neizravno sudjeluju u proizvodnim procesima krajnjih isporučitelja izvoznih dobara (prerađeni poljoprivredni proizvodi, odnosno ugostiteljske usluge koje koriste stranci).

\section{Zaključak}

Rad prikazuje metodološke osnove za dekompoziciju doprinosa pojedinih sastavnica finalne potražnje ukupnom bruto domaćem proizvodu. Za razliku od konvencionalnog pristupa u kojem se doprinos svake od komponenata rashodne strane BDP-a izračunava kao umnožak stope rasta te komponente i udjela u BDP-u, s korištenjem negativnog predznaka kod uvoza, doprinos predloženog modela sastoji se u alokaciji ukupnog uvoza na svaku od sastavnica finalne potražnje koja ga izravno ili neizravno inducira.

Rezultati za Hrvatsku u velikoj mjeri su u skladu s rezultatima ranijih istraživanja za druga gospodarstva (Kranendonk i Verbruggen, 2008; Mellens, Noordman i Verbruggen, 2007). Sastavnice finalne potražnje sa najintenzivnijim uvoznim sadržajem su izvoz i investicije, dok potrošnja države ima nizak uvozni sadržaj.

Ograničenja primijenjenog pristupa proizlaze iz temeljne pretpostavke korištene u input-output analizi o nepromijenjenim tehnološkim koeficijentima. U suvremenom gospodarstvu promjene u tehnologiji proizvodnje znatno su dinamičnije nego ranije, a što utječe na mogućnost brže promjene tehnoloških koeficijentima. S druge strane, izrada input-output tablica zahtijeva značajne resurse, te se one 
prema zahtjevima Eurostata izrađuju samo za svaku petu godinu, što onemogućuje praćenje dinamike godišnje promjene tehnoloških koeficijenata. Izrada tablica ponude i uporabe u stalnim cijenama na godišnjoj razini, a koje su nešto manje kompleksne u odnosu na input-output tablice, uz primjenu odgovarajućih tehnika za raspodjelu uvoza na komponente finalne potražnje, omogućila bi kvalitetnije sagledavanje izvora ukupnog gospodarskog rasta. Nakon što budu dostupne inputoutput tablice za recentnije razdoblje, u budućim istraživanjima naglasak treba staviti na analizu promjena u kretanju učinaka pojedinih sastavnica finalne potražnje. Imajući u vidu sve intenzivniju uključenost Hrvatske u međunarodnu razmjenu i sukladno tome porast udjela uvoza, doprinos pojedinih sastavnica potražnje ukupnom rastu BDP-a, izračunat bez korekcije za uvozni sadržaj, teži precjenjivanju stvarnog učinka.

\section{Literatura:}

Babić, M. (1978). Osnove input-output analize. Zagreb: Narodne novine.

Babić, M. (1980). Utjecaj promjena u tehnološkoj matrici na proizvodnju pojedinih sektora. Ekonomska analiza, 14(2), str. 57-68.

Babić, M. (1983). Strukturne proporcije u projekciji privrednog razvoja. Znanstvene osnove dugoročnog razvoja SR Hrvatske. Zagreb: Ekonomski institut, Zagreb.

Buturac, G., Mikulić, D. i Palić, P. (2019). Sources of export growth and development of manufacturing industry: empirical evidence from Croatia. Ekonomska istraživanja, 32(1), 101-127. (https://doi.org/10.1080/1331677X.2018.1550003)

Buturac, G., Lovrinčević, Ž. i Mikulić, D., (2014). Export Competitiveness of Croatian Textile Industry - CMS Analysis and Importance for Economy. Tekstil Ve Konfeksiyon, 24 (2), 158-168. (http://dergipark.gov.tr/tekstilvekonfeksiyon/issue/23644/251855)

Buturac, G., Lovrinčević, Ž. i Mikulić, D. (2017). International competitiveness and restructuring of the Croatian food industry, Acta Oeconomica, 67(3), 435-462. (https://akademiai.com/doi/10.1556/032.2017.67.3.7)

Buturac, G. i Vizek M. (2015). Izvoz prehrambene industrije i učinci na gospodarstvo: slučaj Hrvatske. Ekonomski pregled, 66(3), 203-230. (https://hrcak. srce.hr/index.php?show=clanak\&id_clanak_jezik=212247)

Dietzenbacher, E. i Van Der Linden, J.A. (1997). Sectoral and spatial linkages in the EC production structure. Journal of Regional Science, 37(2), 235-257. DOI: https://doi.org/10.1111/0022-4146.00053 
Dietzenbacher, E., van Burken, B. i Kondo, Y. (2019). Hypothetical extractions from a global perspective. Economic Systems Research, 1-15. DOI: https:// doi.org/10.1080/09535314.2018.1564135

Dietzenbacher, E. i Lahr, M. L. (2013). Expanding Extractions. Economic Systems Research, 25(3), 341-360. DOI: https://doi.org/10.1080/09535314.2013.774266

Državni zavod za statistiku Republike Hrvatske. (2015). Tablice ponude i uporabe i input-output tablice za 2010. Dostupno na: www.dzs.

Fleissner, P., Böhme, W., Brautzsch, H., Höhne, J., Siassi, J. i Stark, K. (1993). Input-output-analyse. Wien, New York: Springer-Verlag.

Hummels, D., Ishii, J. and Yi, K. (2001). The nature and growth of vertical specialization in world trade", Journal of International Economics, vol. 54, pp. 75-96.

Ivandić, N. i Šutalo, I. (2018). Doprinos turizma hrvatskom gospodarstvu: IO pristup. Ekonomski pregled, 69(1), 20-42.

(https://hrcak.srce.hr/index.php?show=clanak\&id_clanak_jezik=288185)

Jurčić, Lj. (1998). The multiplying effects of Croatian tourism. Acta Turistica, 10(2), str. 128-149.

Jurčić, Lj. (2000). Razvitak input-output analize u Hrvatskoj. Ekonomski pregled, 51(11-12), 1313-1333.

(https://hrcak.srce.hr/index.php?show=clanak\&id_clanak_jezik=45251)

Keček, D., Mikulić, D. i Lovrinčević, Ž. (2019) Deployment of renewable energy: Economic effects on the Croatian economy, Energy policy, 126, 402-410

Kranendonk, H.C. and J.P. Verbruggen (2008), Decomposition of GDP Growth in Some European Countries and the United States, De Economist, 156(3), 295-306. https://doi.org/10.1007/s10645-008-9095-0

Kurz, H. D., Dietzenbacher, E. i Lager, C. (1998). Input-output analysis, Volumes 1-3. Cheltenham: Edward Elgar.

Lovrinčević, Ž., Buturac, G. i Mikulić, D. (2015). Export Performance of the Croatian Wood Industry and its Contribution to the Overall Croatian Economy. Forest products journal, 65 (3/4), 159-165. (https://forestprodjournals.org/doi/10.13073/FPJ-D-14-00063)

Mellens, M.C., H.G.A. Noordman i Verbruggen, J.P. (2007), Re-exports: international comparison and implications for performance indicators, CPB Document 149.

Mikulić, D., Rašić- Bakarić, I. i Slijepčević, S. (2016) The economic impact of energy saving retrofits of residential and public buildings in Croatia. Energy Policy 2016, 96, 630-644. 
Mikulić, D. (2018). Osnove input-output analize s primjenom na hrvatsko gospodarstvo. Zagreb: Ekonomski institut.

Miller, R. E. i Blair, P. D. (2009). Input-Output Analysis: Foundations and Extensions. New York: Cambridge University Press.

Sekulić, M. (1977). Međusektorski model cijena. Problemi privrednog razvoja i privrednog sistema Jugoslavije. Zagreb: Ekonomski institut, Zagreb.

Sekulić, M. (1980). Međusektorski modeli i strukturna analiza. Zagreb: Informator.

Sekulić, M. (1993). Najnoviji razvoj u primjeni input-output analize (strukturna analiza). Zagreb: Ekonomski institut, Zagreb.

ten Raa, T. (2005). The Economics of Input-Output Analysis. Cambridge: Cambridge Univeristy Press.

Timmer, M. P., Dietzenbacher, E., Los, B., Stehrer, R. and de Vries, G. J. (2015), An Illustrated User Guide to the World Input-Output Database: the Case of Global Automotive Production", Review of International Economics., 23: 575-605

United Nations. (1999). Handbook of input-output table compilation and analysis, Studies in Methods, Series F, No. 74. New York: UN.

United Nations. (2008). International standard industrial classification of all economic activities. Statistical papers, Series M No. 4/Rev.4, Revision 4, New York, Department of Economic and Social Affairs.

\title{
METHODOLOGY FOR DECOMPOSITION OF GROSS DOMESTIC PRODUCT TO THE COMPONENTS OF FINAL DEMAND AND APPLICATION FOR CROATIAN ECONOMY
}

\author{
Summary
}

The aim of the paper is to provide a systematic overview of the methodological basis for the decomposition of gross domestic product on final demand components and the application of the presented model to the Croatian economy. The decomposition of the gross domestic product is based on the input-output model. The conventional approach used in calculation of the contribution of individual components of final demand treats imports as an independent variable. However, the alternative model, proposed by this research, distribute imports to the components of the final demand that directly and indirectly induce it. Proposed approach provides a more reliable insight to the actual contribution of each component of final demand. The application of the methodology for the decomposition of gross domestic product to the components of final demand has been empirically applied to the Croatian economy. Based on the results of the analysis, it can be concluded that exports and investments are components of final demand with the highest import content. On the other hand, the lowest import content is found for the government expenditures for final consumption. The results imply that a new model of economic growth based on the growth of exports and 
investment in gross fixed capital necessarily results in a more intense international integration of the Croatian economy. Limitations of the research arise from the application of the standard assumption used in input-output analysis on constant technological coefficients. The contribution of the paper is related to systematic presentation of a methodological approach that enables a more reliable quantification of the contribution of individual components of the final demand in relation to the conventional approach which is usually used.

Key words: input-output analysis, gross domestic product, final demand, import dependency 